This is a pre-copyedited, author-produced PDF of an article accepted for publication in Journal of World Investment and Trade following peer review. The version of record M Paparinskis, 'Investors' Remedies under EU and International Investment Law' (2016) Journal of World Investment and Trade is available online at: $x \times x \times x \times x$.

\title{
Investors' Remedies under EU and International Investment Law
}

Percy: You know, they do say that the Infanta's eyes are more beautiful than the famous Stone of Galveston. Edmund: Mm! ... What? Percy: The famous Stone of Galveston, My Lord. Edmund: And what's that, exactly? Percy: Well, it's a famous blue stone, and it comes ... from Galveston.

Edmund: I see. And what about it? Percy: Well, My Lord, the Infanta's eyes are bluer than it, for a start. Edmund: I see. And have you ever seen this stone?

Percy: (nods) No, not as such, My Lord, but I know a couple of people who have, and they say it's very very blue indeed. Edmund: And have these people seen the Infanta's eyes? Percy: No, I shouldn't think so, My Lord. Edmund: And neither have you, presumably. Percy: No, My Lord. Edmund: So, what you're telling me, Percy, is that something you have never seen is slightly less blue than something else you have never seen. Percy: (finally begins to grasp) Yes, My Lord. ${ }^{1}$

\section{Introduction}

Comparison of European Union ('EU') law with international investment law is, in recent years, an endeavour of apparently ever-increasing rewards. Not that this is an unexpected development. In international trade law, to take an example of a contiguous discipline, normative inquiries of a comparative character that relate to EU and international law have yielded valuable insights. ${ }^{2}$ And it is plainly a sensible idea for practitioners to have inkling about the parameters of applicability and content of law, when multiple rules or regimes are potentially relevant in a particular dispute. In addition, the technical language of the law of treaties, through which the interaction between EU law and investment law is articulated, frames the argument of

\footnotetext{
1 'The Queen of Spain's Beard', The Black Adder, Episode 4 (BBC, first broadcast 6 July 1983); <https://www.youtube.com/watch?v=B6fluCc8b2A> (accessed 1 July 2016).

$2 \mathrm{~J}$ Weiler, 'Epilogue: Towards a Common Law of International Trade' in J Weiler (ed), The EU, the WTO, and the NAFTA: Towards a Common Law of International Trade (OUP 2001); F Ortino, Basic Legal Instruments for the Liberalisation of Trade: A Comparative Analysis of EC and WTO Law (Hart 2004).
} 
interpretation and application in terms of sameness and compatibility ${ }^{3}-$ a topic addressed by Christina Binder elsewhere in this issue. ${ }^{4}$ To sum it up, there are good reasons, some normative, some pragmatic, and some, as it were, incidental to tactical choices within formalised dispute settlement, to engage into comparative inquiries of EU and investment law. The tenor of some of these inquiries, particularly when expressed as dichotomous approaches of 'EU law' and 'international law', each impatiently intolerant of the other, may be unduly reminiscent of grand debates of religious and political philosophy, with less good reasons for that. ${ }^{5}$ But even that is not particularly surprising. The EU legal order has been brisk in its encounters with, say, law of the sea, collective security, as well as regional human rights, ${ }^{6}$ and there is no obvious reason why interaction with international investment law should take place in a gentler manner.

There are, then, good reasons for expecting comparative inquiries between EU and investment law, and, as Mavluda Sattorova explains elsewhere in this issue, important issues to be considered regarding comparison of substantive rules. ${ }^{7}$ However, the narrower comparison of remedies has not been treated as having much importance. The Eureko v Slovakia jurisdictional award (also known as Achmea v Slovakia I) gave short thrift to it in passing, as part of its rejection of alleged prohibition of arbitration by EU law:

The fact that there might be remedies available to the Claimant in national courts through Francovich procedures does not alter the position. One of the central purposes of arbitration is to provide the disputing parties, by their consent, with an alternative to proceedings in national courts. Moreover, an arbitration clause in a BIT is specifically included to address the substantive protections afforded to investors under the BIT. ${ }^{8}$

This, apparently, is the closest that any Tribunal has got to engaging with the comparison of remedies. In Electrabel v Hungary, a citation of a leading Court of Justice of the European Union ('CJEU') judgment on State liability is included in the abbreviations' section but does not appear in the decision itself; ${ }^{9}$ it does not take an excessive leap of imagination to suggest a dutiful assistant preparing a list of all abbreviations that might be relevant, and the Tribunal forgetting to

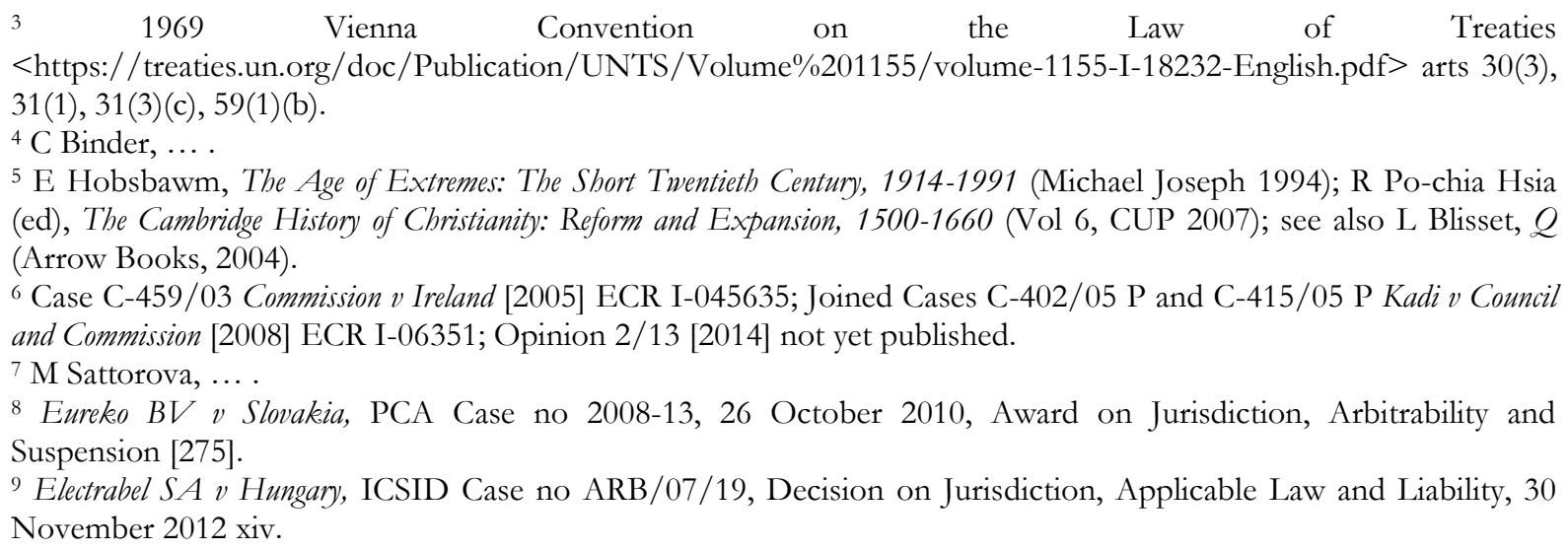


scrub out the ultimately irrelevant ones. Legal writers have been, overall, similarly dismissive. There may be a stray sentence or a descriptive paragraph here and there, ${ }^{10}$ but at least a birds-eye overview of Anglophone writings reveals very few instances of substantial analysis. ${ }^{11}$ Overall, most people seem to view this as a topic of no particular relevance.

Is there something more to remedies in EU and international investment law than catches and has so far caught - the eye? By this point, the reader may suspect that the answer will follow the standard tripartite structure of many an introduction: (1) there is an issue (2) that everybody considers to be irrelevant - (3) wrongly, as the article will demonstrate. However, the thesis of this article, subverting the expected punchline, is that Tribunals and writers have quite properly treated this topic as not worthy of interest. It indeed is not. This argument will proceed in three parts. The first part will set out, as briefly as possible, rules on remedies in EU and investment law (Section II). The second part will identify some reasons to feel cautious about the value of such an inquiry (Section III). The third part will examine, in a relatively brief manner, the limited returns of comparison of remedies, first on issues of principle (Section IV) and then on points of practice (Section V). This article will not address the practicalities of parallel engagement of EU and investment law remedies, which go to the more general point of interaction of EU and investment law. It will also limit the analysis to intra-EU bilateral investment treaties ('BIT'), and will not address the Energy Charter Treaty ('ECT') (to which the EU is a party and thus a possible addressee of remedies). And it will not consider whether the EU is subject to a special regime of international responsibility, nor touch upon the impact that that might have on investment arbitration. ${ }^{12}$ The overall thesis of the article is reflected in the excessively lengthy epigraph: if objects under comparison are vaguely incommensurable, in substantive as well as epistemological terms, the returns from comparative inquiry are very limited indeed.

\section{Setting out Investors' Remedies}

10 TW Walde, 'The "Umbrella" Clause in Investment Arbitration' (2005) 6 J World Investment Trade 183, 221; A Kulick, Global Public Interest in International Investment Law (CUP 2012) 82; A Reinisch, 'Articles 30 and 59 of the Vienna Convention on the Law of Treaties in Action: The Decisions on Jurisdiction in the Eastern Sugar and Eureko Investment Arbitrations' (2012) 39 Legal Issues Economic Integration 157, 167; J Kleinheisterkamp, 'Financial Responsibility in European International Investment Law' (2014) 63 ICLQ 449, 459; P Strik, Shaping the Single European Market in the Field of Foreign Direct Investment (Hart 2014) 240; E Nanopoulos and R Yotova, "Repackaging" Plain Packaging in Europe: Strategic Litigation and Public Interest Considerations' (2016) 19 J Int'l Economic L $175,196-7$.

11 G van Harten, Investment Treaty Arbitration and Public Law (OUP 2008) 104-5, 147-9; I Marboe, 'State Responsibility and Comparative State Liability for Administrative and Legislative Harm to Economic Interests' in S Schill (ed), International Investment Law and Comparative Public Law (OUP 2010) 399-405, 410.

12 Cf. P Eeckhout, EU External Relations Law (2nd edn, OUP 2011) 262-4; and F Hoffmeister, 'Litigating against the European Union and tis Member States - Who Responds under the ILC's Draft Articles on International Responsibility of International Organisations?' (2010) 21 EJIL 723; P Jan Kuijper and E Paasivirta, 'EU International Responsibility and its Attribution: From the Inside Looking Out' in M Evans and P Koutrakos (eds), The International Responsibility of the European Union (Hart 2013). 
It may be convenient to set out the position on investors' remedies under international investment law in terms of knowns and unknowns. ${ }^{13}$ Sometimes, remedies are known knowns, explicitly set out in the applicable treaties. The 2015 Trans-Pacific Partnership ('TPP'), to take a recent and sophisticated example, identifies the remedy of compensation as part of the primary rule of expropriation, and elaborates compensation, restitution, costs, causality, and punitive damages as part of the tertiary rule on awards. ${ }^{14}$ But the intra-EU investment treaties are neither recent nor sophisticated, and as such are unlikely to engage explicitly with remedies other than relating to expropriation. Investors' remedies are therefore known unknowns, albeit unknown in a number of different ways. At the greatest degree of abstraction, they are known in the sense that they are plainly constituted by secondary rules of State responsibility relating to content of responsibility. ${ }^{15}$ But they are also unknown because there is ground for reasonable disagreement on how rules elaborated in the inter-State setting are applicable to responsibility invoked by nonState actors. ${ }^{16}$

In a more practical sense, it is known that compensation is an available remedy - indeed, not to put too fine a point upon it, it is the availability of compensatory remedy that has shaped the international investment law into what it is - but that does not get the practitioner too far. ${ }^{17}$ There is a great deal of unknown regarding real-life issues of compensation, particularly relating to choice and forensic application of methods, timing of valuation, and risks. ${ }^{18}$ Availability of restitution is a known unknown. It is sometimes explicitly addressed in treaty law, and probably

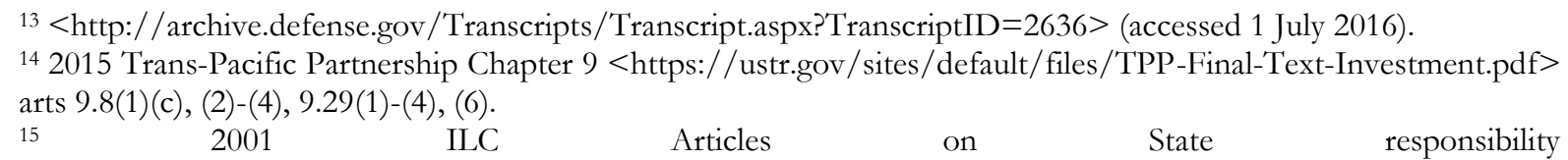
<http://legal.un.org/ilc/texts/instruments/english/draft_articles/9_6_2001.pdf> Part Two.

16 Ibid. art 33(2); S Wittich, 'Investment Arbitration: Remedies' in M Bungenberg and others (eds), International Investment Law: A Handbook (CHBeck/Hart/Nomos 2015).

${ }^{17} \mathrm{It}$ is worth quoting in full the scathing remarks of Judge Rosalyn Higgins: 'The real-life issues that arise relating to compensation are many and complex. Article 36 of the ILC Articles itself side-steps virtually all of these, leaving them unanswered. Paragraph 2 simply provides that "the compensation shall cover any financially assessable damage including loss of profits insofar as it is established". Some of the many issues that are begged by this bland formula do find mention in the Commentary. Others do not. The practitioner in this field gets little from this article or the accompanying pages - the counsel preparing argument or the arbitrator addressing one of the myriad problematic issues when drafting the compensation part of his or her award will look elsewhere for guidance. Article 36(2) will serve simply as a point of departure, a rule that will be recited before turning to the real problems in the field', $\mathrm{R}$ Higgins, 'Overview of Part Two of the Articles on State Responsibility' in J Crawford and others (eds), The Law of International Responsibility (OUP 2010) 539.

18 I Marboe, 'Valuation in Cases of Expropriation' in Bungenberg (n 16) 1058 ('convergence as regards the required standard does, however, not answer the most important question, namely how to arrive at a determined sum. It turns out that implementing this standard in practice is a difficult task.'); I Marboe, 'Valuation in Cases of Breaches of International Law Unrelated to Expropriation' ibid. 1082-3 ('the number and type of obligations breached in most cases appears to be irrelevant for the valuation of the economic loss caused by the act of the State'). Cf. the discussion of 'wide discretion in fashioning a damages award', L Yong, 'GAR Live Lookback: Recent Treaty Cases and the Damages Fog' Global Arbitration Review (9 June 2016). 
always available in principle under custom. But its practice of implementation is so dependent on the shared position of parties that it may be better read as providing a particular formula for settlement of dispute, rather than a legal remedy as such. Availability of moral damages is a known known ${ }^{19}$ (but probably erroneously so, since it is doubtful that a breach of a primary rule on treatment of objects, rather than entities, can give rise to such damage in the first place). And availability of compound interest in principle is a known known, just as everything relating to practicalities of its calculation is a known unknown. ${ }^{20}$

While remedies available to investors under international law have to be squeezed through the needle-hole of investor-State treaty-based arbitration, remedies available under EU law are much more varied, both in terms of content and of the procedural settings in which they can be advanced. The rest of the article will mainly engage with State liability in domestic courts, described in a recent CJEU judgment in the following terms:

According to settled case-law, EU law confers a right to compensation where three conditions are met: the rule of law infringed must be intended to confer rights on individuals; the infringement must be sufficiently serious; and there must be a direct causal link between the breach of the obligation resting on the State and the damage sustained by the injured parties (see, inter alia, judgments in Brasserie du Pêcheur and Factortame, Joined Cases C-46/93 and C-48/93, EU:C:1996:79, paragraph 51; Danske Slagterier, C-445/06, EU:C:2009:178, paragraph 20, and Commission v Italy, C-379/10, EU:C:2011:775, paragraph 40$).^{21}$

This implementation of liability takes place through domestic rules and courts, albeit buttressed by the minimum standards of EU law:

It must be recalled that where the conditions for a State to incur liability are satisfied, a matter which it is for the national courts to determine, it is on the basis of national law that the State must make reparation for the consequences of the loss or damage caused, provided that the conditions laid down by national law in respect of reparation of loss or damage are not less favourable than those relating to similar domestic claims (principle of equivalence) and are not so framed as to make it, in practice, impossible or excessively difficult to obtain reparation (principle of effectiveness) (see judgment in Fuß, C-429/09, EU:C:2010:717, paragraph 62 and the case-law cited) ${ }^{22}$

\footnotetext{
19 P Dumberry, 'Moral Damages' in Bungenberg (n 16) 1141 ('analysis of recent investor-State case law shows ... that monetary compensation is the appropriate remedy for moral damages affecting an individual or corporation').

20 Niko Resources (Bangladesh) Ltd. v Bapex and Petrobangla, ICSID Cases no ARB/10/11 and ARB/19/18, Decision on Implementation of the Decision on the Payment Claim, 14 September 2015 [113]-[164]; J Gotanda, 'Interest' in Bungenberg (n 16) 1152.

${ }^{21}$ Case C-98/14 Berlington Hungary Tanácsadó és Szolgáltató kft and Others v Magyar Állam [2015] ECLI:EU:C:2015:386 [104]; see generally K Lenaerts and others, EU Procedural Law (OUP 2014) Chapter 5.

${ }^{22}$ C-160/14 João Filipe Ferreira da Silva e Brito and Others v Estado português [2015] ECLI:EU:C:2015:565 [50].
} 
But this is only one element in the tapestry of rules and remedies that individuals can rely upon. ${ }^{23}$ At the level of Member States, individuals could rely upon principles of primacy, direct and indirect effect, and equivalent and effective protection; at the level of the EU, in appropriate circumstances individuals could directly or indirectly challenge conduct of its institution. ${ }^{24}$

\section{Reasons for Caution of Comparisons}

There are three reasons for caution when engaging in a comparative inquiry of this kind. The broadest concern relates to comparison of procedural matters in international law more generally. It may be best introduced through the well-known debate about the relationship between most-favoured-nation ('MFN') clauses and rules of international dispute settlement. Arbitral decisions and legal writers usually discuss the possible applicability of MFN clauses through a variety of dyads: substance/procedure, jurisdiction/admissibility, and presence/absence of consent. ${ }^{25}$ But one may also pick on the textual expression of the clause 'most favoured nation' - and ask a different question: are various regimes of dispute settlement sufficiently similar to be commensurable in terms of greater and lesser favourability in the first place ${ }^{26}$ Whether or not that is the right question to ask about MFN clauses, ${ }^{27}$ it does point to the more general concern about comparing procedures: it may well be the case that 'their different features reflect the structural differences between the two systems. It cannot be said in abstract that one system is better than the other'. ${ }^{28}$ It does not mean that no valuable insights can be gained from comparisons of procedural matters. Quite to the contrary, such writings, both at the level of domestic ${ }^{29}$ and international dispute settlement, engage with systemic issues in a fine and

\footnotetext{
23 A Ward, Judicial Review and the Rights of Private Parties in EU Law (OUP 2007).

${ }^{24}$ Lenaerts (n 19) Part III.

${ }^{25}$ C Greenwood, 'Reflections on "Most Favoured Nation” Clauses in Bilateral Investment Treaties' in D Caron and others (eds), Practicing Virtue: Inside International Arbitration (OUP 2015); S Schill, 'Maffezini v Plama: Reflections on the Jurisprudential Schism in the Application of Most-Favored-Nation Clauses to Matters of Dispute Settlement' in M Kinnear and others (eds), Building International Investment Law: The First 50 Years of ICSID (Kluwer Law International 2015).

${ }^{26}$ M Paparinskis, 'MFN Clauses and International Dispute Settlement: Moving beyond Mafferini and Plama?' (2011) 26(2) ICSID Rev - Foreign Investment L J 14, 34-56.

27 This perspective has been explicitly taken in some arbitral decisions, ICS Inspection and Control Services Limited (UK) $v$ Argentina, PCA Case no 2010-9, Award on Jurisdiction, 10 February 2012 [318]-[325]; Daimler Financial Services AG v Argentina, ICSID Case no ARB/05/1, Award, 22 August 2012 [240]-[250], and treaty practice elaborating the meaning of MFN clauses as not extending to rules of international dispute settlement endorse it by necessary implication, TPP Ch 9 ( $\mathrm{n}$ 14) art 9.5(3). The best response to this argument is succinctly given in Hocbtief AGv Argentina, ICSID Case no ARB/07/31, Decision on Jurisdiction, 24 October 2011 [100].

28 G Sacerdoti, 'Panelists, Arbitrators, Judges: A Response to Joost Pauwelyn' (2016) 109 AJIL Unbound $283,287$.

${ }^{29} \mathrm{R}$ Assy, Injustice in Person: The Right to Self-Representation (OUP 2015).
} 
nuanced manner. ${ }^{30}$ But they still depend on certain shared assumptions about role, structure, and function of procedural institutions. ${ }^{31}$ It is not at all obvious that remedies sketched out in the previous Section - tucked away in different procedural corners of different legal orders, to a large part prima facie different, and significantly different even when prima facie similar - share much at all, even in the loosest sense.

The second concern is more practical: would EU and investment law remedies ever occupy the same legal space, so as to be available to particular investors? Countless exam questions have asked undergraduate students to compare dispute settlement procedures available under the United Nations Convention on the Law of the Sea: 'Advise Patagonia on whether to bring the case to the International Court of Justice, International Tribunal on Law of the Sea ('ITLOS'), or an Annex VII Tribunal. ${ }^{32}$ That is a sensible question, since the same substantive rules are likely to be applicable in all the procedural settings. While simultaneous applicability it is not a prerequisite of comparative analysis of procedural rules, ${ }^{33}$ the returns of an inquiry into various remedies of investors that are rarely available to actual investors would be very limited indeed. As a general matter, rules of EU law and international investment law have different criteria of application and different content, ${ }^{34}$ so for a sense of a real-life relevance of comparison one might consider the possibility of repackaging some of the leading cases into remedies, as it were, of the other side.

Many of the leading CJEU judgments on liability claims in economic matters would face difficulties in clearing jurisdictional hurdles as investment claims. Sometimes no foreign economic interests are involved in the first place, ${ }^{35}$ sometimes the protection that investment treaties provide for economic ventures frustrated at the inception may prove to be too limited; ${ }^{36}$ and sometimes cause of action seems to relate to trading transactions, rather than investments capable of protection through investment treaties and dispute settlement. ${ }^{37}$ It may, however, be

\footnotetext{
${ }^{30} \mathrm{E}$ Lauterpacht, Aspects of the Administration of International Justice (Grotius 1991); J Collier and V Lowe, The Settlement of Disputes in International Law: Institutions and Procedures (1 ${ }^{\text {st }}$ edn, OUP 1999); C Brown, A Common Law of International Adjudication (OUP 2007); A Sarvarian, Professional Ethics at the International Bar (OUP 2013).

${ }^{31}$ D Caron, 'International Courts and Tribunals: Their Roles amidst a World of Courts' (2011) 26(2) ICSID Rev Foreign Investment L J 1; V Lowe, 'The Function of Litigation in International Society' (2012) 61 ICLQ 209.

32 Or a Chamber of ITLOS, <https://www.itlos.org/cases/list-of-cases/case-no-23/>.

33 See materials at nn 27-8.

34 See $n 7$.

${ }^{35}$ Case C-392/93 R v HM Treasury, exparte British Telecommunications plc [1996] ECR I-163 [2]; Case C-5/94 The Queen $v$ Ministry of Agriculture, Fisheries and Food, ex parte: Hedley Lomas (Ireland) Ltd. [1996] ECR I-02553 [2]-[11].

${ }^{36}$ Joined Cases C-46/93 and C-48/93 Brasserie du Pêcheur SA v Germany, and R v Secretary of State for Transport, ex parte Factortame Ltd and Others [1996] ECR I-1029 [11].

37 Brasserie du Pêcheur and Factortame ibid. [3]; Case C-319/96 Brinkmann Tabakfabriken v Skatteministeriet [1996] ECR I5255 [8]-[13].
} 
that some claims relating to taxation could raise colourable issues under investment law. ${ }^{38}$ It is harder to say whether the investment claims could have been presented through EU remedies after all, there are good tactical reasons for investors to characterise their claims so as to evade EU law - but the prima facie sense is that, while (certain aspects of) the claim may be governed by EU law, it would not usually give rise to liability claims for breach of EU law.

The third concern relates to peculiar optics that one has to adopt to compare remedies under EU and investment law. It leaves aside the question of whether these remedies can coexist. From the EU law perspective, this question is to be answered by reference to compatibility of EU and investment law; from investment law perspective, it is addressed in procedural conditions of investor-State arbitration, which may either preclude pursuit of remedies in domestic courts (by fork-in-the-road clause or waiver), require it (domestic litigation requirement), or leave the issue open. Plainly, comparison of complementary remedies raises very different questions than if they are mutually exclusive. It also leaves aside the available remedies under domestic public and private law that do not draw upon EU law, as well as the possibility of applying international investment law through the remedial framework of domestic law. ${ }^{39}$ And it does not cover remedies that could be available to investors under other regimes of international law, particularly but not exclusively regional human rights law. ${ }^{40}$ Overall, to compare EU and investment law remedies is to pose a question in a distinctly odd and strained manner, with little bight of either conceptual issues or likely practical considerations. With this caution in mind, the next two sections will set out the limited returns that providing an answer will bring.

\section{Comparing the Principle of Investors' Remedies}

It is useful to begin by summarising the general position under both regimes. Under EU law, there are three necessary criteria for a successful State liability claim for compensation: 'the rule of law infringed must be intended to confer rights on individuals; the infringement must be sufficiently serious; and there must be a direct causal link between the breach of the obligation

\footnotetext{
${ }^{38}$ Joined Cases C-397/98 and C-410/98 Metallgesellschaft Ltd and Others (C-397/98), Hoechst AG and Hoechst (UK) Ltd (C-410/98) v Commissioners of Inland Revenue and HM Attorney General [2001] ECR I-01727 [26]-[32]; cf. A Gildemeister, L'arbitrage des différends fiscaux en droit international des investissements (LGDJ 2013).

${ }^{39}$ E.g. Case no 2009-113-0106, Judgment of the Constitutional Court of the Republic of Latvia, 6 October 2010 <http://www.satv.tiesa.gov.lv/wp-content/uploads/2009/12/2009-113-0106_Spriedums_ENG.pdf> [21]-[26].

${ }^{40}$ E.g. OAO Neftanaya Kompaniya Yukos v Russia App no 14902/04 ECHR Judgment of 20 September 2011. Another regime of possible relevance is double taxation, which may provide for a right of arbitration with the State, 2014 OECD Model Convention with Respect to Taxes on Income and on Capital $<$ https://www.oecd.org/ctp/treaties/2014-model-tax-convention-articles.pdf > 25(5).
} 
resting on the State and the damage sustained by the injured parties'. ${ }^{41}$ Under international investment law, just as under international law more generally, there are two necessary criteria for a successful claim: attribution of conduct to the State under international law, and breach of an international obligation of the State. ${ }^{42}$ It may be that EU State liability and State responsibility are underpinned by the same assumptions. ${ }^{43}$ But they are structured in very different ways. Domestic law is relevant for international investment law in various ways (more so perhaps than for any other regime of international law), but State responsibility for its breach is entirely determined by primary and secondary rules of international law, interpreted and applied by an international arbitral tribunal. Conversely, for EU law, implementation of liability takes place through domestic rules and courts, buttressed by the EU law principles of equivalence and effectiveness. ${ }^{44}$ The significant differences in structure and applicable law make comparison challenging, both on issues of principle discussed in the following paragraphs, and practical effects dealt with in the next section.

It may be useful to consider in turn several cross-cutting issues. First, why is attribution to the State an element of State responsibility under international investment law but not State liability under EU law? The smug public international lawyer might point to this as one example of the archaism of EU law, which evidently has not yet made the important conceptual step of articulating attribution as a separate juridical category -- something that international law achieved already some time ago. ${ }^{45}$ That is unfair (and not only because it overstates the speed with which the taxonomy was adopted by the great and the good of international law): ${ }^{46}$ at least some of the accepted international rules of attribution ${ }^{47}$ seem very similar to principles elaborated in the CJEU cases, partly on the point of State liability and partly relating to the concept of State more broadly. ${ }^{48}$ On this point, even though EU law does not bring out attribution as a separate criterion, similarities are significant.

\footnotetext{
41 Berlington Hungary Tanácsadó és Szolgáltató kft (n 20) [104].

422001 ILC Articles (n 15) art 2.

${ }^{43}$ C-224/01 Gerhard Köbler v Republik Österreich [2003] ECLI:EU:C:2003:513 [32].

${ }^{44}$ C-160/14 João Filipe Ferreira da Silva e Brito and Others v Estado português [2015] ECLI:EU:C:2015:565 [50].

${ }^{45} \mathrm{R}$ Ago, 'Le délit international' (1939) 68 Recueil des Cours 415, 450-1.

46 Oppenheim, to take the standard positivist international law text, always wrote in terms of State responsibility for acts of State organs and private persons, L Oppenheim, International Law (Vol. I: Peace, Longmans 1905) 206-14; L Oppenheim, International Law (Vol. I: Peace, $2^{\text {nd }}$ edn, Longmans 1912) 214-25 (with a delightful footnote at $212 \mathrm{fn}$ 1); R Jennings and A Watts, Oppenheim's International Law (Vol. I: Peace, 9 ${ }^{\text {th }}$ edn, Longman 1992) 541-54; similarly I Brownlie, System of the Law of Nations: State Responsibility (Clarendon Press 1983) Chs VII-VIII.

47 S Olleson, ‘Attribution in Investment Treaty Arbitration' (2016) 31 ICSID Rev - Foreign Investment L J 457.

48 Cf. 2001 ILC Articles (n 15) art 4 and Köbler (n 42) [31]-[32] ('principle applies to any case in which a Member State breaches Community law, whichever is the authority of the Member State whose act or omission was responsible for the breach. ... In international law a State which incurs liability for breach of an international commitment is viewed as a single entity, irrespective of whether the breach which gave rise to the damage is attributable to the legislature, the judiciary or the executive. That principle must apply a fortiori in the Community legal order since all State authorities, including the legislature, are bound in performing their tasks to comply with
} 
Secondly, is the concept of directly effective rights, an explicit criterion of EU State liability, paralleled in international investment law? To a certain extent, it is: the terminology of direct rights has been used by some writers to discuss whether investors are beneficiaries of primary obligations of investment protection (a point on which reasonable people disagree). ${ }^{49}$ This is most certainly not the place to take stock of debates about direct rights in various legal orders. ${ }^{50}$ But it is plain that the role of these arguments is very different. For EU law, a claim about State liability will not be successful in the absence of directly effective rights. For investment law, a claim about State responsibility that ticks the boxes of attribution, breach, and relevant procedural conditions will be successful, whether or not the investor has invoked responsibility as a beneficiary of a primary obligation. The character of investors' rights may well have implications in terms of State responsibility and law of treaties, ${ }^{51}$ but it most certainly is not a criterion for a successful claim. ${ }^{52}$

Thirdly, how would the 'sufficiently serious breach' of EU law fit within international investment law? This question may be considered on a number of levels. Prima facie there is a fairly significant difference: for EU law, as the CJEU recently recalled,

the factors which the referring court may be required to take into consideration include the clarity and precision of the rule infringed, the scope of the discretion conferred by the rule on the national or EU authorities, whether the infringement and the damage caused were intentional or involuntary, whether any error of law was excusable or inexcusable, and the

\footnotetext{
the rules laid down by Community law which directly govern the situation of individuals'); 2001 ILC Articles (n 15) art 5 and the recent confirmation in Case C-282/10 Maribel Dominguezv Centre informatique du Centre Ouest Atlantique, Préfet de la région Centre [2012] ECLI:EU:C:2012:33 [38]-[39] ('where a person is able to rely on a directive not as against an individual but as against the State he may do so regardless of the capacity in which the latter is acting ... the entities against which the provisions of a directive that are capable of having direct effect may be relied upon include a body, whatever its legal form, which has been made responsible, pursuant to a measure adopted by the State, for providing a public service under the control of the State and has for that purpose special powers beyond those which result from the normal rules applicable in relations between individuals'). It is less clear whether rules on attribution of conduct of directed or controlled entities that do not exercise public powers, 2001 ILC Articles (n 15) art 8 -- of importance in investment disputes relating to conduct of State-owned companies -- would fall within the principle expressed in the latter. And see 2016 Canada-EU Economic and Trade Agreement <http://trade.ec.europa.eu/doclib/docs/2016/february/tradoc_154329.pdf > Ch 18.

49 Cf. Z Douglas, The International Law of Investment Claims (CUP 2009) Ch 1; R Volterra, 'International Law Commission Articles on State Responsibility and Investor-State Arbitration: Do Investors Have Rights?' (2010) 25 ICSID Rev-Foreign Investment L J 218; A Roberts, 'Triangular Treaties: The Extent and Limits of Investment Treaty Rights' (2015) 56 Harvard Int'l L J 353.

50 'Revisiting V an Gend en Loos: A Joint Symposium with the International Journal of Constitutional Law (I•CON)' (2014) 25 EJIL i, 83-199; 'Revisiting V an Gend en Loos: A Joint Symposium with the European Journal of International Law $\begin{array}{lllllll}\text { (EJIL)' (2014) } & 25 & \text { Int'l } & \text { J } & \text { Const } & \text { L } & \text { 94-213; }\end{array}$ $<$ http://www.oxfordjournals.org/our_journals/ejilaw/ejil_icon_symposium.html>.

51 M Paparinskis, 'Analogies and Other Regimes of International Law' in Z Douglas and others (eds), The Foundations of International Investment Law: Bringing Theory into Practice (OUP 2014).

${ }^{52}$ The smug international lawyer noted above would again perceive similarities between State liability and the classic definition of State responsibility with its focus on injury, which has now faded into the background, A Pellet, 'The Definition of Responsibility in International Law' in Crawford (n 17) 5-6, 8-10.
} 
fact that the position taken by an EU institution may have contributed to the omission, adoption or maintenance of national measures or practices contrary to EU law. ${ }^{53}$

Conversely, in investment law the general principle is that State responsibility will arise from $a$ breach of an international obligation, whether it is clear or vague, precise or imprecise, with broad, narrow, or no discretion, breached voluntarily, and so on. ${ }^{54}$ For an international lawyer, CJEU position has distinctly dated overtones, ${ }^{55}$ but the smugness may again be at last partly misplaced. Historically, 'sufficiently serious breach' was elaborated by the CJEU as a less restrictive alternative to fault; ${ }^{56}$ a concept that international law has been struggling with itself for quite some time. ${ }^{57}$ There is also another and more interesting parallel. It is plainly the case that international law may express legal rules either at the level of general secondary rules or particular primary obligations. And it is well known that the moulding of important elements of the international law on protection of aliens and investments in the first half of the last century took place in parallel to some mild confusion about the line between these primary rules and secondary rules of State responsibility. With very slight squinting, it is possible to identify similarities between 'sufficiently serious breach' and some of the leading authorities regarding primary obligations in international investment law, both in traditional ${ }^{58}$ and modern practice. ${ }^{59}$ And it is plausible to suggest that these developments, expressed in technically very different ways as they are, have been animated by similar concerns about safeguarding domestic decisionmaking process from excessively intrusive international review. ${ }^{60}$ Overall, despite the prima facie impression, there are some similarities.

Fourthly, what comparative insights are yielded by the final criterion of State liability under EU law, 'a direct causal link between the breach of the obligation resting on the State and the

\footnotetext{
${ }^{53}$ Case C-318/13 X [2014] ECLI:EU:C:2014:2133 [42].

542001 ILC Articles (n 15) Part One Chapter III; cf. 'serious breaches of obligations under peremptory norms of general international law', ibid. Part Two Chapter III.

55 Oppenheim $1^{\text {st }}$ edn (n 45) 203 ('An act of a State injurious to another State is nevertheless not an international delinquency if committed neither wilfully and maliciously nor with culpable negligence').

56 Brasserie du Pêcheur and Factortame (n 35) [75]-[80].

${ }^{57}$ Brownlie (n 45) 40-46; Oppenheim 9th edn (n 45) 508-9; A Gattini, 'Smoking/No Smoking: Some Remarks on the Current Place of Fault in the ILC Draft Articles on State Responsibility' (1999) 10 EJIL 397; B Stern, 'The Elements of an Internationally Wrongful Act' in Crawford (n 17) 209-10.

${ }^{58}$ LFH Neer and Pauline Neer (US v Mexico) (1926) 4 RIAA 60, 61-2 ('an outrage, ... bad faith, ... wilful neglect of duty, or ... an insufficiency of governmental action so far short of international standards that every reasonable and impartial man will readily recognise its insufficiency').

59 Mesa Power Group, LLC v Canada, PCA Case no 2012-17, Award, 24 March 2016 [502]-[505]; Crystallex International Corporation v Venezuela, ICSID Case no ARB(AF)/11/2, Award, 4 April 2016 [540]-[545]; Philip Morris v Uruguay, ICSID Case no ARB/10/7, Award, 8 July 2016 [320] ('transparency and the protection of the investor's legitimate expectations; freedom from coercion and harassment; procedural propriety and due process, and good faith), [398][400]; CETA (n 47) art 8.10(2).

${ }^{60}$ Mesa ibid. [505] ('international law requires tribunals to give a good level of deference to the manner in which a state regulates its internal affairs'); Philip Morris ibid. [399] ('investment tribunals should pay great deference to governmental judgments of national needs in matters such as the protection of public health').
} 
damage sustained by the injured parties'? That may sound similar to the statement of principle in the law of State responsibility -- '[t]he State responsible for the internationally wrongful act is under an obligation to compensate for the damage caused thereby ${ }^{61}$ - but the certainty with which both points are expressed is to a considerable extent based on unknowns. In international law, causality may differ in relation to different primary rules, ${ }^{62}$ and the formulation and application of rules may become unclear when multiple causes, including contribution to injury, are at play. ${ }^{63}$ Unsurprisingly, the factually complex international investment law disputes have led to significant disagreements about causation, perhaps most famously in the CME and Lauder claims against the Czech Republic. ${ }^{64}$ On the EU law side, causality would be determined and implemented through domestic law. The early concerns that causality-related peculiarities in domestic law would entirely undermine State liability ${ }^{65}$ have so far not materialised. ${ }^{66}$ But the underlying point that causality is a matters of domestic law, lightly buttressed by principles of equivalence and effectiveness - themselves very much a moveable feast ${ }^{67}$ - is entirely right, suggesting that there may be significant differences in standards of liability in various legal systems. Overall, apparent similarities upon a closer consideration dissolve into unknowns.

It may be useful to take stock of analysis so far by reference to the concept of incommensurability, explained by Timothy Endicott as distinguishable between two kinds. Incommensurability is radical when there is no rational basis for comparing any two objects in a given domain, e.g. blueness of the sky and a person's mood; it is vague when some pairs can be compared in respect of some properties, and some cannot, e.g. blueness of turquoise and navy. ${ }^{68}$ Much depends, of course, on the type of quality that is being measured - e.g. blueness of the cover of procedural rules may not be commensurable, but the time of their adoption will be ${ }^{69}$-but for most legal inquiries into remedies $\mathrm{EU}$ law and investment law are vaguely

\footnotetext{
612001 ILC Articles (n 15) art 36(1) (emphasis added).

62 J Crawford, State Responsibility: The General Part (CUP 2013) 492-4.

63 Ibid. 495-503; I Plakokefalos, 'Causation in the Law of State Responsibility and the Problem of Overdetermination: In Search of Clarity’ (2015) 25 EJIL 471.

${ }^{64}$ Cf. Lauder v Czech Republic, UNCITRAL Case, Final Award, 3 September 2001 [214]-[235], [288]; CME v Czech Republic, UNCITRAL Case, Partial Award, 13 September 2001 [580]-[584].

${ }^{65}$ F Smith and L Woords, 'Causation in Francovich: The Neglected Problem' (1997) 46 ICLQ 925.

66 T Lock, 'Is Private Enforcement of EU Law through State Liability a Myth? An Assessment 20 Years after Francovich' (2012) 49 CMLR 1675, 1689, 1697-9.

${ }^{67}$ M Dougan, 'The Vicissitudes of Life at the Coalface: Remedies and Procedures for Enforcing Union Law before the National Courts' in P Craig and G de Búrca (eds), The Evolution of EU Law (2nd edn, OUP 2011).

68 T Endicott, 'Proportionality and Incommensurability' in G Huscroft and others (eds), Proportionality and the Rule of Law: Rights, Justification, Reasoning (CUP 2014) 319-20.

69 Cf. the azure 2012 ICC Rules of Arbitration <http://www.iccwbo.org/Data/Documents/BuisnessServices/Dispute-Resolution-Services/Mediation/Rules/2012-Arbitration-Rules-and-2014-Mediation-Rules-

ENGLISH-version/> and the teal 2014 UNCITRAL Rules on Transparency in Investor-State Treaty-Based Arbitration $<$ https://www.uncitral.org/pdf/english/texts/arbitration/rules-on-transparency/Rules-onTransparency-E.pdf $>$.
} 
incommensurable. These remedies are not radically incommensurable: comparison of attribution, direct rights, breach, and causality may not be particularly rewarding, but it is not nonsensical.

But they do seem vaguely incommensurable, in at least two ways. The first is epistemological: there are significant gaps of knowledge about properties under comparison. On the investment law side, recent treaty-makers have made some contribution to elaboration of the law on remedies, but these rules are unlikely to be applicable in the intra-EU setting. Arbitral jurisprudence constante on basic legal principles goes hand in hand with significant differences regarding the technical aspects of calculation of compensation, dispositive for the final amount of the award. On the EU law side, implementation of State liability through domestic law and courts results in a great role for domestic law, noted above in relation to causality but equally applicable to calculation of damages. ${ }^{70}$ To sum it up, investment law remedies are unclear, and EU law remedies are mostly not within the EU law. The second aspect of incommensurability relates to the systemic optic: if investment law, with only mild oversimplification, is compensatory remedies, principles and remedies of the EU law are much more diverse. So it may be unclear, say, whether State liability under the EU law could be invoked against the State when the conduct in question has been carried out by a State-owned company not exercising public powers. Or it may be the case that the availability or amount of compensation in a State liability claim may fail to match international investment law. But these are matters that the EU law may well address in systemically very different ways that do not resort to pecuniary remedies, e.g. through horizontal effect of fundamental freedoms, or non-pecuniary remedies, and so on. Overall, even if the knowledge about properties under comparison were available - vel non many aspects of properties themselves are so different that they are incommensurable.

\section{Comparing the Practice of Investors' Remedies}

Investors' remedies in EU and international investment law are incommensurable on points of legal principle, or so the previous section sought to suggest. But it is possible that the argument took a wrong turn somewhere and ended up excessively formalistic and theoretical, while a closer look at the causes of action and amount in damages in the practice of remedies could provide a clearer sense of their relative merits. If that is a question to consider, it is plausible to expect that international investment law would be more favourable in that sense. While not quite on the precise point of interest in this paper, the comparative analysis of remedies available

\footnotetext{
$70 \mathrm{~T}$ de la Mare, 'State Liability Claims in the English Courts' in Celebrating 20 years of Francovich in the EU (17 November 2011) <http://www.biicl.org/files/5812_delamare_17-11-11_biicl.pdf> [7.3].
} 
under investment law, on the one hand, and the law of the UK and Canada, on other hand, is in line with this intuition. ${ }^{71}$

As noted in the previous section, domestic law plays an important role in EU State liability claims, particularly in relation to causality, damages, and procedural conditions, therefore practice in various Member States ('MS') may very well be different. A sensible way of approaching the issue could therefore be to consider the practice of remedies in relation to particular States that have been addresses of remedies of both kinds. The challenge is picking the right case studies because States are often experienced with only one type of remedies. For example, Tobias Lock's very fine analysis of the UK and German practice on State liability under EU law could provide the perfect benchmark for a comparative argument, ${ }^{72}$ but is unhelpful because there are no publicly available final decisions in investment claims against these States, ${ }^{73}$ and so on. With mild arbitrariness and in light of the public international law perspective of this journal, the next paragraphs will consider the practice of remedies in relation to those EU MS that have, in practice, faced international investment claims. The argument will proceed in two uneven parts. First, I will take stock of the experience of number of Central and Eastern European MS that acceded to the EU in 2004 and have faced quite a few intra-EU investment claims after that. Secondly, I will focus on Spain; a MS of the EU already in 1991, when Francovich $v$ Italy was handed down, and a respondent State in quite a few pending and recently decided investment claims. ${ }^{74}$ Ideally, this would show, even with inevitable sloppiness regarding (finer) points of domestic law, how investors' remedies have fared when advanced against the same respondent in practice.

Some States combine substantial experience in being respondents in investment claims on the basis of intra-EU BITs ${ }^{75}$ with little practice in EU State liability claims. The first example is Latvia. It has two pending intra-EU BIT cases $^{76}$ but apparently no State liability claims, even

\footnotetext{
${ }^{71}$ NJ Calamita, 'The British Bank Nationalizations: An International Law Perspective' (2009) 58 ICLQ 119; A de Mestral and R Morgan, 'Does Canadian Law Provide Remedies Equivalent to NAFTA Chapter 11 Arbitration?' CIGI Investor-State Arbitration Series (Paper no 4 - May 2016) $<$ https://www.cigionline.org/sites/default/files/isa_paper_no.4.pdf >. Reasonable people have disagreed regarding the US law, cf. L Johnson and O Volkov, 'Investor-State Contracts, Host-State "Commitments" and the Myth of Stability in International Law' (2013) 24 Am Rev Int'l Arbitration 361; P Parvanov and M Kantor, 'Comparing U.S. Law and Recent Investment Agreements: Much More Similar than You Might Expect' (2010-2011) Ybk Int'l Investment L Policy.

72 Lock (n 66). See also the 2007 Francovich Follow-Up <http://www.asser.nl/upload/eelwebroot/www/documents/Dossiers/FrancovichFollowUp.pdf> 44-63.

73 See the UK, <http://investmentpolicyhub.unctad.org/ISDS/CountryCases/221?partyRole=2>, and Germany, $<$ http://investmentpolicyhub.unctad.org/ISDS/CountryCases/78? partyRole $=2>$.

$74<$ http://investmentpolicyhub.unctad.org/ISDS/CountryCases/197? partyRole=2>.

75 The information about investment arbitrations is taken from UNCTAD Investment Policy Hub, $<$ http://investmentpolicyhub.unctad.org/ISDS $>$, with the usual caveat that there may be other cases that are not publicly available. Claims by non-EU investors will not be taken into account.

$76<$ http://investmentpolicyhub.unctad.org/ISDS/CountryCases/115? partyRole=2>.
} 
though the principle of State liability has been confirmed by necessary implication by both the Constitutional and Supreme Courts. ${ }^{77}$ Czech Republic seems to be an even clearer instance: since 2004, it has dealt with 21 intra-EU investment claims, both on the basis of BITs and the Energy Charter Treaty, brought by investors from the Netherlands, Luxembourg, Germany, Cyprus, and United Kingdom. ${ }^{78}$ Conversely, on the point of EU State liability, ${ }^{79}$ the discussion so far appears to have been related to the point of principle of how EU and domestic liability regimes could be reconciled. A 2012 Supreme Court's judgment concluded that the absence of appropriate domestic rules does not preclude the application of State liability in line with the CJEU case law, ${ }^{80}$ but it is not clear how far the implementation of this principle in actual cases has proceeded. Slovakia's and Hungary's experience with remedies seems similar to examples considered above: while having been respondents in intra-EU claims in respectively $6^{81}$ and 10 cases, ${ }^{82}$ their experience with EU liability claims ${ }^{83}$ appears to be so far very limited. ${ }^{84}$

In other States, there is (limited) experience with both kinds of remedies, perhaps even more so on the EU State liability side. Lithuania has lost one intra-EU BIT claim for the breach of fair and equitable treatment in privatisation process. ${ }^{85}$ Under EU law, ${ }^{86}$ it has so far $^{87}$ won two State liability claims: in one case, a EUR 4.5 million claim was rejected because no breach of EU law had taken place, ${ }^{88}$ while in the other case no causality existed, despite a breach of a Directive. ${ }^{89}$ Estonia has a pending claim brought by a Dutch investor. ${ }^{90}$ Relating to EU law, ${ }^{11}$ the Supreme

77 Constitutional Court, Case no 2010-71-01, Judgment, 19 October $2011<$ http://www.satv.tiesa.gov.lv/wpcontent/uploads/2010/11/2010-71-01_Spriedums_ENG.pdf> [14.4]; Supreme Court's Civil Matters Department, $\begin{array}{lllll}\text { Case no } & \text { C27187611, } & \text { Judgment, } & 20 & \text { November }\end{array}$ $<$ https://manas.tiesas.lv/eTiesasMvc/nolemumi/pdf/192441.pdf > [7.2].

78 This number does not include cases settled and discontinued, $<$ http://investmentpolicyhub.unctad.org/ISDS/CountryCases/55?partyRole=2>.

${ }^{79} \mathrm{I}$ am grateful to Vojtěch Bartoš and Lenka Popovičová for their assistance with Czech practice.

80 Supreme Court of the Czech Republic, Case no 28 Cdo 2927/2010, Decision, 20 August 2012 $<$ http://demo.eurocases.eu/Doc/CourtAct/4513105>.

81 This number does not include cases settled and discontinued, $<$ http://investmentpolicyhub.unctad.org/ISDS/CountryCases/191?partyRole=2>.

82 This number does not include cases settled and discontinued, $<$ http://investmentpolicyhub.unctad.org/ISDS/CountryCases/94?partyRole=2>.

${ }^{83}$ I am grateful to Zuzana Vikarská for her assistance with Slovak practice, and to Laura Gyeney and Csongor István Nagy for their assistance with Hungarian practice.

${ }^{84}$ Case C-430/13 Ilona Baradics and others v QBE Insurance (Europe) Ltd Magyarországi Fióktelepe, Magyar Állam [2014] ECLI:EU:C:2014:32 [45].

${ }^{85}$ Luigiterzo Bosca v Lithuania, PCA Case no 2011-05, Award, 17 May 2013.

${ }^{86} \mathrm{I}$ am grateful to Žygimantas Pacevičius and Vita Sabalyte for their assistance with Lithuanian practice.

${ }^{87}$ Reportedly, in early 2016 lower administrative courts awarded 18,533.63 EUR to 34 claimants for the breach of Directive 90/314/EEC (Package Travel Directive). The judgments are not publicly available and may be reversed on appeal.

88 Supreme Administrative Court of Lithuania, Case no A-146-69/2012, 30 January 2012 $<$ http://infolex.lt/tp/337148>

89 Kaunas Regional Administrative Court, Case no I-3294-402/2014, 16 December 2014 $<$ http://infolex.lt/tp/943777>. The judgment was not appealed to the Supreme Court and became final.

90 United Utilities (Tallinn) BV and Aktsiaselts Tallinna Vesi v Estonia, ICSID Case no ARB/14/24.

${ }^{91}$ I am grateful to Carri Ginter and Lisette Suik for their assistance with Estonian practice. 
Court has confirmed that the more restrictive rules of domestic liability would not apply to EU State liability claims. ${ }^{92}$ While courts mostly reject such claims due to lack of sufficiently serious infringement, ${ }^{93}$ a 2015 judgment by the Supreme Court did award EUR 3000 for the breach of Package Travel Directive. ${ }^{94}$ Poland has been a respondent in 8 intra-EU cases. ${ }^{95}$ As far as EU claims go, ${ }^{96}$ there is some practice of bringing them in the Polish courts, ${ }^{97}$ and the grounds for rejecting claims include the traditional criteria of the lack of direct rights ${ }^{98}$ and lack of a causal link. $^{99}$

The separate case of Spain requires slightly more legwork. Since 2011, it has faced 26 intraEU claims, mostly on the basis of the ECT and in relation to renewable energy investments. ${ }^{100}$ The 2007 version of the Asser Institute Report finds seven judgments by Spanish courts, rendered between 1995 and 2004, that touch upon issues EU State liability. From the cases that engage with the substance of the issue, 3 reject claims because no breach has taken place, and 4 award damages, ${ }^{101}$ including the 2003 CSD case where EUR 26.4 million in damages were awarded. ${ }^{102}$ There may be some inconsistency in more recent cases dealing with EU State liability claims for discriminatory rules on withholding of dividends of recipient companies resident in other MS, found by the CJEU to be in breach of the EU law. ${ }^{103}$ While the Spanish courts initially accepted liability claims, ${ }^{104}$ in a number of cases rendered in 2012 it took the view that the breach had not been sufficiently serious due to uncertainty about the proper position

\footnotetext{
${ }^{92}$ Supreme Court, Administrative Law Chamber, Case no 3-3-1-84-12, Judgment, 31 October 2013.

93 Tallinn Circuit Court, Case no 3-05-613, Decision, 26 January 2007; Tallinn Circuit Court, Case no 3-11-2682, Decision, 17 December 2014; Tallinn Circuit Court, Case no 3-14-50825, Decision, 26 April 2016.

94 Supreme Court, Administrative Law Chamber, Case no 3-3-1-80-14, Judgment, 26 February 2015 (mitigation principles from domestic law resulted in award of half of actual loss claimed).

95 This number does not include cases settled and discontinued, $<$ http://investmentpolicyhub.unctad.org/ISDS/CountryCases/94? partyRole $=2>$.

${ }^{96} \mathrm{I}$ am grateful to Wojciech Sadowski and Patrycja Treder for their assistance with Polish practice.

${ }^{97}$ Judgment of the Court of Appeal in Warsaw of 9 November 2011, ref. no I ACa 386/11 (Legalis no 473517); Judgment of the Court of Appeal of 5 December 2012, ref. no I ACa 582/12 (Legalis no 1025724); Decision of the Polish Supreme Court of 19 June 2013, ref. no I CZ 59/13 (Legalis no 759435).

98 The Polish Supreme Court held that Art. 5 (1) of the Directive no 1999/93/EC of the European Parliament and the Council of 13 December 1999 on a Community framework for electronic signatures did not intend to give a right for filing appeals in the electronical form to the national courts, Decision of the Polish Supreme Court of 19 June 2013, ref. no I CZ 59/13, Legalis no 759435.

${ }^{99}$ Judgment of the Court of Appeal in Warsaw of 9 November 2011, ref. no I Aca 386/11, Legalis no 473517.

$100<$ http:/ /investmentpolicyhub.unctad.org/ISDS/CountryCases/197? partyRole =2>.

101 Asser Report (n 72) 59-62.

${ }^{102}$ F Castillo de la Torre, 'Case Note' (2004) 41 CMLR 1717.

103 Case C-487/98 EC v Spain [2010] ECLI:EU:C:2010:310 [69]-[75].

${ }^{104}$ Case no. 508/2011 (2 October 2012)
} 
under the EU law at the time of the breach. ${ }^{105}$ The latter position has been criticised in legal writings as being an excessively narrow reading of the position under the EU law. ${ }^{106}$

\section{Conclusion}

How do remedies under EU and investment law compare? Not very well, this article has sought to argue. There are good reasons to be cautious about an inquiry into remedies that is framed in such terms: procedural matters are not easy to compare, particularly if they have significantly different systemic assumptions and relate to mostly different substantive matters. The comparison is not nonsensical - concepts of attribution, breach, rights, and causality do evoke somewhat similar considerations - but ultimately the extent of systemic differences as well as lack of information about crucial aspects of remedies make these matters incommensurable. It is not obvious that comparison of practice gets the argument much further than the comparison of principle. Plainly, some EU MS have considerable experience with investors' remedies under EU law, others under investment law, and yet others under both EU and investment law. And some investors choose to pursue remedies under one system, others under the other, yet others under domestic law, other regimes of international law, or particular contractual arrangements, or some combination of some or all of the above. If the amount of money awarded were the only criterion for evaluating the remedy, then it is plausible to expect that an investment claim would be often more attractive, although not invariably so. ${ }^{107}$ But even leaving aside the underlying assumption that remedies may be available in relation to the same conduct, the amount of money cannot be the whole story, as the rich and diverse empirical literature on reasons for bringing investment claims suggest. ${ }^{108}$ At the end of the day, both the principle and practice of remedies are too different to be meaningfully commensurate: granted, a non-answer of not the most exciting sort, but perhaps the process of its articulation has been, as virtue, its own reward. ${ }^{109}$

\footnotetext{
105 Judgment of the Supreme Court of 22 September 2014; rec. núm. 390/ 2012; Judgment of the Supreme Court of 22 September 2014, rec. no. 394/2012; Judgment of September 26, 2014, rec. no. 667/2012.

${ }^{106}$ E Cobreros Mendazona, 'La exigibilidad del requisito de la violación suficientemente caracterizada al aplicar en nuestro ordenamiento el principio de la responsabilidad patrimonial de los Estados por el incumplimiento del Derecho de la Unión Europea' (January-April 2015) Revista de Administración Pública 11.

${ }^{107}$ It has been recently suggested that mean average of amount awarded in all cases is USD 16.6 million, S Franck and L Wylie, 'Predicting Outcomes in Investment Treaty Arbitration' (2015) 65 Duke L J 459, 494-7, which is less than the - admittedly exceptional - CSD judgment of EUR 26.4 in Spanish courts.

${ }^{108} \mathrm{R}$ Wellhausen, 'Recent Trends in Investor-State Dispute Settlement' (2016) 7 J Int'l Dispute Settlement 117, 122 8; C Dupont, T Schultz, and M Angin, 'Political Risk and Investment Arbitration: An Empirical Study' (2016) 7 J Int'l Dispute Settlement 136.

${ }^{109}$ Except if the CJEU decides to approach the preliminary reference arising out of Eureko (n 8) in just these terms, $<$ http://juris.bundesgerichtshof.de/cgibin/rechtsprechung/document.py?Gericht=bgh\&Art=en\&client=12\&nr=74612\&pos=0\&anz=1\&Blank=1.pdf $>$.
} 
